\title{
Transformation of health communication literacy in the pandemic era
}

\author{
K. Y.S Putri
}

Communication Department, Faculty of Social Sciences, Universitas Negeri Jakarta, Indonesia

Email: kinkinsubarsa@unj.ac.id

Deddy Mulyana

Communication Department, Faculty of Communication, Universitas Padjajaran, Indonesia

Email: deddymulyana96@yahoo.com

\section{S Bekti Istiyanto}

Communication Department, Faculty of Social and Political Sciences, Universitas Jenderal Soedirman, Indonesia

Email:bektiis@yahoo.com

\section{Linda Zakiah}

Primary School Teacher Education Department, Faculty of Education, Universitas Negeri Jakarta, Indonesia

Email:lindazakiah@unj.ac.id

\section{Rayni Delya Hafni}

Communication Department, Faculty of Social Science, Universitas Negeri Jakarta, Indonesia

Email: RayniDelyaHafni_1410618001@mhs.unj.ac.id 


\begin{abstract}
Indonesian public health communication literacy is the education center for the government and related institutions. The formulation of this research problem is how to model health communication literacy in communities in tourism areas in Indonesia. The research objective was to determine the health communication literacy model in the community in tourism areas in Indonesia. The concept used in this research is new media literacy and health communication and audience attitudes. Several previous studies support this research. The method used is quantitative by distributing questionnaires to respondents. The result of the research is that health communication literacy on social media in a cognitive structure greatly affects the respondents. However, at the conative level, there are still some respondents who do not care about this pandemic because of the long duration. In the simple regression results, this study shows a great influence on the respondent's attitude. The suggestion of this research is the need for knowledge collaboration in subsequent research. So that it is not only in social science research but with natural science.
\end{abstract}

Keywords: HOAX News, health communication, health literacy, new media

\title{
INTRODUCTION
}

Covid-19 is a global pandemic that has had a devastating impact on the human and social dimensions. After spreading from China, the pandemic spread rapidly to 210 countries including Indonesia (Herdiana, 2020). Data regarding the confirmation of Covid-19 in Indonesia were 549,508, while active cases in Indonesia were 73,429 cases, 458,880 recovered and 17,199 people died (SATGAS COVID-19, 2020). In the dissemination and source of information regarding Covid-19 news, of course, using social media and one of the most used platforms today is Instagram (IG) (Jusuf, 2020). According to data released by Napoleon Cat, in the January-May 2020 period, Instagram users in Indonesia reached 69.2 million $(69,270,000)$ users. This achievement is an increase from month to month for the use of the Instagram platform. The skyrocketing use of this platform is also inseparable from the work from home (WFH) policy that the company has implemented for its employees amid the Covid-19 pandemic (MS, 2017)always interested in trying an information or something new and not knowing what the consequences are. Children and adolescents are directed to utilize the Internet as a useful source of information in learning and not 
just a choice of desirable and enjoyable information. Every day children and adolescents are always close and. They learn more from the media learning to learn. The reality of the next community is not much-expected education from the media, the media function as a medium of information, education, and entertainment. Internet media is an important tool to help learn and in achieving the desired quality of life. In this case media literacy needed for children and adolescents in interpreting information received through the media and the internet. This can be done by the family, school and at the government level in cooperation with partners and related agencies. Media literacy education should be conducted not only for children and adolescents but all the layers of the community Mahasiswa Pascasarjana Universitas Negeri Sebelas Maret Darwadi MS (parents, teachers, NGOs, CSOs, Orsos, etc..

In using social media to find information about Covid-19, of course, you need to understand information technology. The Association of Indonesian Internet Service Providers (APJII) and Polling Indonesia, informed that the Indonesian population who is internet literate is around 64.8 percent of the total. This means that out of the 264.16 million people in Indonesia, 171.17 million people are already using the internet (JPNN, 2019).

With the Covid-19 pandemic, besides making people use social media more and looking for information there, this pandemic also has an impact on the tourism sector in Indonesia. (Sugihamretha, 2020). The pressure on the tourism industry is most evident in the large decline in foreign tourist arrivals with massive cancellations and decreases in bookings. The decline also occurred due to a slowdown in domestic travel, especially due to the reluctance of Indonesians to travel, worried about the impact of Covid-19. The Center for Statistics (BPS) noted that foreign tourist arrivals (tourists) who came to the country in early 2020 had decreased. During January 2020, foreign tourist visits reached 1.27 million visits. This figure has decreased by 7.62 percent when compared to the number of foreign tourist arrivals in December 2019 of 1.37 million visits. The decline in the number of foreign tourist visits was mainly due to the outbreak of Covid-19 which occurred in the last week of January 2020 (Sugihamretha, 2020).

The Covid-19 pandemic has had a profound impact on the flow of tourist visits and has greatly affected the tourism business in Tual City (Rikumahu, 2020). Apart from Tual City, the tourism industry in Nusa Penida, Bali was also affected by the outbreak of the coronavirus which caused the visit rate to drop dramatically (Mustofa, 2020). Thus, the number of foreign tourists visiting 
Nusa Penida, which averages around 1.5 thousand -2.3 thousand more foreign tourists per day, now the number is less than 1,000 visits. (Jubaedah $\&$ Anas, 2019).

The city of Bukittinggi, West Sumatra (West Sumatra) has also experienced a decline in tourist visits due to the impact of Covid-19 (Arianti, 2017). Likewise, with what happened in Bandung, where based on data from the West Bandung Regency Tourism and Culture Office, the level of tourist visits to tourist attractions until August 2020 was 1.2 million people, compared to 2019 there was a sharp decline (Mawardi, 2020). The impact of the Covid-19 pandemic was also felt in the Makassar tourism sector, which immediately became paralyzed (Mattola, 2020).

Thus proving that the Covid-19 pandemic, besides having an impact on human health, is also able to paralyze the tourism sector. With so many impacts that have occurred in Indonesia, the number of news spreads has also increased, the Ministry of Communication and Information Technology has the results of monitoring from the AIS Team of the Directorate General of Aptika, showing 1,401 hoax content and disinformation about Covid-19 circulating in the public (Jusuf, 2020).

The use of information technology will stick with new media, new media in the form of digital media, computers, and information and communication networks in the 20th century. Most of the technologies described as new media are digital, often have the characteristics of being manipulable, networked, compact, incompressible, interactive and impartial. In simple terms, new media is media that is formed from the interaction between humans and computers and smartphones and the internet in particular. This includes the web, blogs, online social networks, online forums and others that use computers as their medium. New media is a medium that facilitates interaction between sender and receiver (MS, 2017)always interested in trying an information or something new and not knowing what the consequences are. Children and adolescents are directed to utilize the Internet as a useful source of information in learning and not just a choice of desirable and enjoyable information. Every day children and adolescents are always close and. They learn more from the media learning to learn. The reality of the next community is not much-expected education from the media, the media function as a medium of information, education, and entertainment. Internet media is an important tool to help learn and in achieving the desired quality of life. In this case media literacy needed for children and adolescents in interpreting information received through the 
media and the internet. This can be done by the family, school and at the government level in cooperation with partners and related agencies. Media literacy education should be conducted not only for children and adolescents but all the layers of the community Mahasiswa Pascasarjana Universitas Negeri Sebelas Maret Darwadi MS (parents, teachers, NGOs, CSOs, Orsos, etc.

Meanwhile, media literacy is a new concept in Indonesia, but studies in other countries in the world have been carried out. To deal with mass media exposure, media literacy activities are strategic to protect the audience from the attack of mass media impressions. In Indonesia, media literacy activities are driven more by concerns that the media can have a negative impact (Setyaningsih, 2017).

Health communication literacy is very important to have knowledge and understanding of disease and is believed to help in the detection, management, and prevention of disease. In addition, it can monitor the development of symptoms of the disorder, effective self-help for mild to moderate symptoms and provide proper first aid to other people with health problems. However, health literacy has received less attention so this has an impact on the lack of public health literacy for both adolescents and adults. This can lead to delays in the detection of early symptoms and appropriate treatment actions for health problems (Grace, 2020).

Health communication is the art of informing, influencing and motivating individuals, institutions and society about important issues in health care in improving the quality of life and health of individuals in society (Liliweri, 2009).

Health literacy is 1 . Media selection for health service information needs, 2. Determination of reference sources in cross checking the truth, and 3. Integrated health decision making (Prasanti, 2018). Tourism communication is a process of equating shared meanings among the participants, which in this case are the stakeholders who support tourism development. The tourism communication model is part of communication practices that can practically provide nuances of renewing tourism activities (Bakti, 2018).

Hoax news is information or news that contains things that are not certain or which are really not facts. Not only by the mainstream media, nowadays hoaxes are very much circulating in the community through online media (Juliswara, 2017).

Another thing regarding health literacy is explained by Fuady (2020) that it is important in information literacy because it is an important aspect that is 
owned by every individual. There are several fields of information literacy, one of which is health literacy. Good health literacy is expected to be able to become agents of change in society to disseminate information.

Because the lack of health literacy will cause hoaxes in the health sector to make people uneasy and many are trapped to believe it. Hoax in the health sector is considered more dangerous than other types of hoax because it has a fatal impact that can threaten a person's life. The spread of hoaxes in the health sector is dangerous and needs to be countered. One way to fight this is by promoting information literacy through online groups (Juditha, 2019).

The tourism industry is one that has also experienced paralysis due to this pandemic, in which all tourist destinations must be temporarily closed for an unpredictable time, in order to anticipate the transmission of the Corona virus or Covid-19. (Walakula, 2020).

The studies above discuss Covid-19, hoaxes, tourism, and some also discuss public health literacy to anticipate efforts to spread hoaxes. All of these studies use a quantitative approach. The difference between previous studies and current research lies in the discussion of Covid-19 health communication literacy in several tourism areas in Indonesia. Research like this has never been done before, so this is what is new and important to research.

So, based on the data above, the formulation of this research problem is how the health communication literacy model in the Corona virus pandemic in tourism areas in Indonesia? The research objective was to determine the health communication literacy model for the Coronavirus pandemic in tourism areas in Indonesia.

\section{LITERATURE REVIEW}

As for the previous research conducted by Putri (2020) regarding framing of health communication on content Islamic religious education in new media shows that health communication is needed by the community. In addition, the use of new media in developing health communication can also be used. This has similarities with research that will be carried out at this time, namely regarding health communication and how it will impact the community if you understand it.

In addition, this study also uses new media as a research medium which is related to the spread of hoax news that researchers want to raise, because hoax news is usually spread in new media (Setyowati, 2020). 
As for the previous research conducted by Putri (2020) regarding the impact of new media literacy and supply chain knowledge management on community economy in Indonesia, that the use of information communication technology has brought enormous benefits to human life. In using information technology, this research also shows that it makes people able to access information and can also see hoax news. This is also related to the research researched by researchers in which new media is used, besides that in Putri's research, it is about the economy in Indonesia, while in this study it discusses Indonesian tourism which of course has a linkage in the economic field.

In the research conducted by Rahmawati, et.al (Rahmawati, 2019) that communication and information technology is an application of knowledge and skills used in providing access to information and messaging with the aim of helping solve human problems in order to achieve communication goals. However, with the development of the times, fake news (hoax) has increased in intensity. The impact of this also in this study can lead to a decrease in incoming foreign tourists. This study has a similarity, namely the decline in tourists in Indonesia, one of which is triggered by hoaxes.

Other than that, Adila (Adila, Weda, \& Tamitiadini, 2019) has research on the development of Pancasila-based literacy and information models in warding off hoaxes. This research reveals that the lack of media literacy in society leads to superficiality of knowledge on social media. In accordance with the government movement that has been pioneered, namely fighting hoaxes using the values of Pancasila and Bhineka Tunggal Ika. This research has a difference, namely if in Adila's research using the values of Pancasila and Bhineka Tunggal Ika, then in our study we use health communication literacy.

Meanwhile, in Husain's research (2020) It was explained that during this pandemic period, it caused concern for medical personnel to contract the Covid-19 virus, which was caused by the patient not being open to extracting information on the patient's disease. For this reason, health communication literacy is needed so that communication can be good and effective so that it does not cause a problem, especially hoax news that will create new problems.

As described by Megasari (2020) that the spread of fake news or hoaxes has had a very bad impact because this news is not only fooling the public with disinformation, but the hoax news is also used by irresponsible parties to divide society and endanger the unity of the Indonesian nation.

In addition to other studies by Santoso (2020) the need to provide 
assistance to Elderly Family Development (BKL) cadres to increase literacy and understanding of the physical and mental health of the elderly during the COVID-19 period through WhatsApp social media, so that news circulating in WA is true news and not hoax information. Our research has something in common, namely by using social media in delivering literacy so that hoax news does not circulate on social media.

Research conducted Chumairoh (2020) explained that the Covid-19 issue has circulated a lot of false information that has troubled the public. The public also doubts and is in a position that sometimes can differentiate between hoaxes and sometimes not because of the large amount of information they get every day. Public panic about Covid-19 has resulted in hoaxes being circulated in the hope that this information can be useful for both prevention and cure.

However, there are also people who do not spread Covid-19 hoaxes because they understand literacy by knowing that the information is untrue, useless, and endangers the health of others, and wants to break the chain of spreading hoaxes to oneself. The positive thing from knowing literacy is what we as researchers expect where the community is able to distinguish true news from hoaxes so that hoaxes do not spread and do not harm society or other sectors such as health and tourism (Juditha, 2020).

\section{METHODS}

This study uses a quantitative approach using a survey as a data collection method. The survey is a data collection method using a questionnaire as a research instrument (Leavy, 2017). The questionnaire in this study was distributed to 132 respondents who have special criteria, in several research areas, which are tourism areas in Indonesia. Furthermore, the data were analyzed using IBM SPSS Statistics 16.0. The validity of the data was tested using $\mathrm{KMO}$, then the reliability of the data was tested using Alpha Croanbach's. The result, research in this study shows that the questionnaire in this study is an appropriate measuring tool, so that further tests can be carried out. The KMO value for health literacy variables was 0.88 with a significance of 0.000 , then the $\mathrm{KMO}$ value for hoax information was 0.67 with a significance of 0.000 , then the $\mathrm{KMO}$ value for audience attitudes was 0.79 with a significance of 0.000 . To deepen the research results, researchers also conducted in-depth observations and interviews with several informants, face-to-face. 


\section{RESULTS AND DISCUSSION}

The results of this study are on univariate research data in health communication, hoax information and all positive attitudes. Likewise, hoax information and attitudes. By having a positive value, this indicates a positive influence. The following is descriptive data of the variables studied.

Table 1: Descriptive data of health communication, hoax information, and audience attitudes

\begin{tabular}{|c|c|c|c|}
\hline No & Variable & Dimension & Percentage \\
\hline \multirow[t]{5}{*}{1} & \multirow{5}{*}{$\begin{array}{l}\text { Health } \\
\text { communication }\end{array}$} & 1. Communicators & $73 \%$ \\
\hline & & 2. Communicate & $61 \%$ \\
\hline & & 3. Message & $74 \%$ \\
\hline & & 4. Media & $81 \%$ \\
\hline & & 5. Effect & $63 \%$ \\
\hline \multirow[t]{3}{*}{2} & \multirow[t]{3}{*}{ Health Literacy } & 1. Media selection & $78 \%$ \\
\hline & & $\begin{array}{l}\text { 2. Determination of reference } \\
\text { sources }\end{array}$ & $77 \%$ \\
\hline & & 3. Health decision making & $76 \%$ \\
\hline \multirow[t]{3}{*}{3} & Attitudes & 1. Cognitive & $82 \%$ \\
\hline & & 2. Affective & $83 \%$ \\
\hline & & 3. Conative & $77 \%$ \\
\hline
\end{tabular}

Table 1 shows that in the health communication variable, there is a communicator dimension with $73 \%, 61 \%$ communicants, $74 \%$ messages, $81 \%$ media, and $63 \%$ effects. All percentages of the dimensions that exist in health communication have a percentage above the average so that the results are very good and have a positive value. With, the lowest percentage of the communicants.

Meanwhile, the health literacy variable has the dimensions of media selection with $78 \%$, determination of reference sources with $77 \%$, and health decision making has $76 \%$, which means that it is also good value because it is above average. With the lowest percentage of health decision making.

In the attitude variable, it has a cognitive dimension with a value of 
$82 \%$, affective with $83 \%$, and conative with a value of $77 \%$. With the lowest percentage is conative.

From the univariate data above, it can be seen that the health communication variable has been maximized in the media dimension, but is still weak in the communicant dimension. This shows if the respondent is good at using communication media but not yet effective from themselves when they receive the information (communicant).

In the health literacy variable, the media selection dimension has a high value, this shows that respondents have chosen the media they use and like effectively, but are still not good at making their health decisions.

In the attitude variable, the respondent was good affectively, but not conatively good.

However, this still means that the variables of health communication, health literacy and attitude have positive results.. The results of this study have similarities with the research of Putri (2020) where true news or not a hoax has provided health information correctly. When these variables have positive results, it shows good public health communication literacy in dealing with various hoax information on Covid-19 news in tourism areas in Indonesia. So, in addition to restoring economic growth, it can also be following the current health protocol so that proper health communication literacy will greatly help the community.

Other than that Putri (2020) In his research, states that new media from various social and mobile platforms will tend to have high customization, increase the relationship between organizations and customers, this provides an increase in the effectiveness of using communication to be able to distinguish hoax information or not as well as the social and interactive nature of users. The all-online, viral, and "value of mouth" nature of the new media with growing consumer participation in organizational communications. And this will facilitate the relationship of the health communication literacy model in the presence of hoax information on news of the coronavirus pandemic in Indonesia's tourism areas.

The next statistical test is a linear regression by predicting the research model of health communication, health literacy, and audience attitudes. The following is the research model 


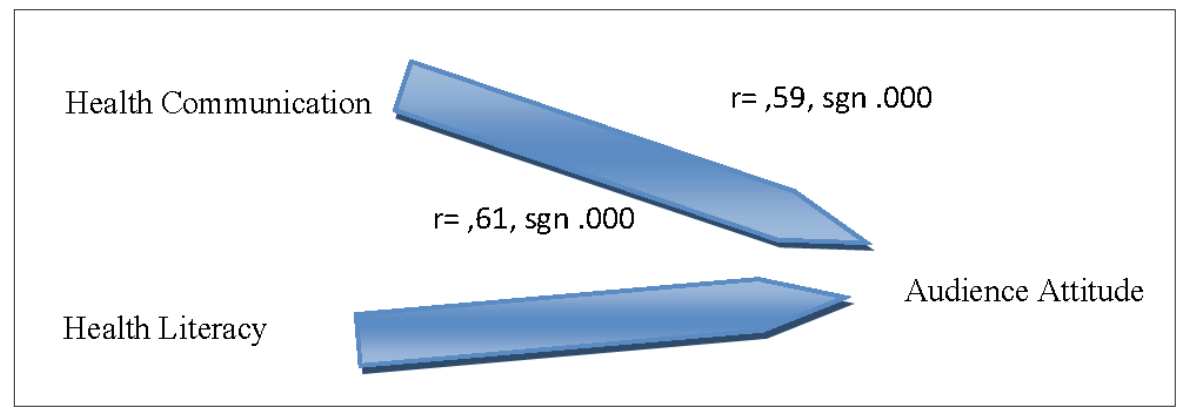

Figure 1: Model of health communication, health literacy, and audience attitudes

The X1 variable, namely Health Communication, has a linear regression value of 0.59 with a significant 0.000 on Variable Y, namely Attitude Audience, this shows that Health Communication has an influence on Audience Attitude. Likewise, Variable X2, namely Health Literacy, has a regression result of 0.61 , with a significant value of 0.000 on Variable Y, namely Attitude Audience, which also shows that Health Literacy has an influence on Audince's Attitude.

The planting of a health communication literacy model regarding hoax information on Covid-19 news in tourism areas in Indonesia has influenced the attitudes of the public. Health literacy and health communication can also influence people's behavior. Health literacy and communication have motivated people to adopt healthy habits in behaving cleanly and to be able to see their attitudes when they are in tourist attractions. With Rahmawati's (2019) that health literacy and communication can be realized in society thanks to communication and information technology which is the application of knowledge and skills used to provide access to information. And when the public has also been able to see fake news (hoax), the impact of hoax news will not cause a decrease in incoming foreign tourists.

On the other hand, Adila (2019) revealed that the development of literacy and information models will be able to ward off hoaxes. With the influence of media literacy in society, it will lead to knowledge on social media about hoax news. 
Husain (2020) revealed that the established health communication literacy aims to ensure that communication is good and effective so that it does not cause a problem, especially hoax news that will create new problems.

Like Megasari (2020) also revealed that in the spread of fake news or hoaxes, this is very fatal because this news not only fools the public with untrue information but is also used by irresponsible parties to divide society. and will endanger the unity of the Indonesian nation. With the results of our research, the impact of health communication and health literacy will make a good thing if people understand the importance of this so that it can make changes in people's attitudes that are good too.

In addition to the results of our research, it is also related to Santoso (2020) 's research where the need to provide assistance to the community to increase literacy and understanding of physical and mental health during the COVID 19 period through social media, so that the news circulating is true news and not hoax information.

Our research also relates to Fuady's (2020) research that literacy and communication are important because they are important aspects of society. The influence of good health literacy can make people become agents of change in society to disseminate information.

The influence of health literacy also raises public attitudes and knowledge about hoaxes in the health sector so that it does not make people worry and believe it. Chumairoh's research (2020) is also related to the results of our research where the issue of Covid-19 has been circulating about false information that has troubled the public. However, with the influence of literacy and health communication, it turns out that it affects people's attitudes where they don't spread Covid-19 hoaxes because they understand literacy by knowing that the information is untrue, useless, and endangers the health of others, and wants to break the chain of spreading hoaxes to oneself. just alone.

The positive thing about the influence of health literacy and health communication is that the attitude of the community is able to distinguish true news from hoaxes so that hoaxes do not spread and do not harm the community or other sectors such as health and tourism. Because the tourism industry is one that is experiencing paralysis due to this pandemic, in which all tourist destinations have to close temporarily, in order to anticipate the spread of the corona virus or covid-19, so health literacy and health communication are very important. 
The health communication literacy model in hoax information on Coronavirus news in tourism areas is of great value. As hoaxes usually make several claims contained in textual representations. Text can take a variety of forms from images of seemingly unlikely situations, to literary fakes to journalistic descriptions of tourism that do not match reality or have been manipulated or interpreted to appear fanciful or highly unusual (Putri, 2020).

Textual representations are then shared through several communication channels, through new media, or one of Instagram. After the hoax was published, it caused an audience reaction, so that if the hoax was successful, the hoax would be taken seriously (Putri, 2020). With this, when the public health communication literacy model is good, there is no need to worry about the impact of hoax information regarding Covid-19 news and the tourism and health sectors will not be affected by the hoax news.

\section{CONCLUSION}

The result of the research is that health communication literacy on social media in a cognitive structure greatly affects the respondents. However, at the conative level, there are still some respondents who do not care about this pandemic because of the long duration. In the simple regression results, this study shows a great influence on the respondent's attitude. The suggestion of this research is the need for knowledge collaboration in subsequent research. So that it is not only in social science research but with natural science.

\section{ACKNOWLEDGEMENT}

The researcher would like to thank Dean of Faculty of Social Sciences Universitas Negeri Jakarta, Dean of Faculty of Communication Universitas Padjajaran, Dean of Faculty of Social and Political Sciences Universitas Jenderal Soedirman, and Dean of Faculty of Education Universitas Negeri Jakarta for all the supports during this research.

\section{REFERENCES}

Adila, I., Weda, W., \& Tamitiadini, D. (2019). Pengembangan model literasi dan informasi berbasis Pancasila dalam menangkal hoaks. WACANA: 
Jurnal Ilmiah Ilmu Komunikasi, 18(1), 101-111. https://doi.org/10.32509/ wacana.v18i1.721

Arianti, D. (2017). Pengaruh sektor pariwisata terhadap perekonomian dan keruangan Kota Bukittinggi (Pendekatan analisis input output). Jurnal Wilayah Dan Lingkungan, 2(3), 183-196. https://doi.org/https://doi. org/10.14710/jwl.2.3.183-196

Bakti, I., Sumartias, S., Damayanti, T., \& Nugraha, A. R. (2018). Pengembangan model komunikasi pariwisata berbasis kearifan lokal di kawasan geopark Pangandaran. Jurnal Kajian Komunikasi, 6(2), 217. https://doi. org/10.24198/jkk.v6i2.18459

Chumairoh, H. (2020). Ancaman berita bohong di tengah pandemi covid-19. Vox Populi, 3(2017), 22-30. https://doi.org/10.24252/vp.v3i1.14395

Fuady, I. (2020). Efektivitas komunikasi kesehatan dalam meningkatkan literasi kesehatan pencegahan HIV AIDS bagi siswa SMA di Kabupaten Pangandaran. Jurnal Pengabdian Kepada Masyarakat, 2(11)., 919-922. Retrieved from http://jurnal.unpad.ac.id/pkm/article/view/20379

Grace, S. B., Gandha, A., \& Tandra, K. (2020). Komunikasi efektif dalam meningkatkan literasi kesehatan mental. Jurnal Komunikasi, 12(2), 191210. https://doi.org/http://dx.doi.org/10.24912/jk.v12i2.5948

Herdiana, D. (2020). Rekomendasi kebijakan pemulihan pariwisata pasca wabah corona virus disease 2019 (Covid-19) di Kota Bandung. Jurnal Master Pariwisata (JUMPA), 7(1), 1-30. https://doi.org/10.24843/ jumpa.2020.v07.i01.p01

Husain, A. H. Al. (2020). Komunikasi kesehatan dokter dan pasien berbasis kearifan lokal Sipakatau di masa pandemi. Jurnal Ilmu Komunikasi, 18(2), 126-141. https://doi.org/10.31315/jik.v18i2.3546

JPNN. (2019). 64 persen penduduk Indonesia melek internet, sumbangsih Banten lebih besar dari Jakarta. Www.Jpnn.Com; JPNN.com. https://www.jpnn.com/ news/64-persen-penduduk-indonesia-melek-internet-sumbangsih-bantenlebih-besar-dari-jakarta\#: : :text=64 Persen Penduduk Indonesia Melek Internet\%2C Sumbangsih Banten Lebih Besar dari Jakarta,-Minggu\%2C 19 Mei\&text=jpnn.com\%2C JAKARTA - Diolah,8 persen dari jumlah total.

Jubaedah, I., \& Anas, P. (2019). Dampak pariwisata bahari terhadap ekosistem terumbu karang di perairan Nusa Penida, Bali. Jurnal Penyuluhan Perikanan Dan Kelautan, 13(1), 59-75. https://doi.org/10.33378/jppik.v13i1.124 
Juditha, C. (2019). Literasi informasi melawan hoaks bidang kesehatan di komunitas online. Jurnal Ilmu Komunikasi, 16(1), 77-90. https://doi. org/10.24002/jik.v16i1.1857

Juditha, C. (2020). Perilaku masyarakat terkait penyebaran hoaks covid-19. Jurnal Pekomnas, 5(2), 105-116. https://doi.org/10.30818/jpkm.2020.2050201

Juliswara, V.(2017). Mengembangkan modelliterasi media yangberkebhinnekaan dalam menganalisis informasi berita palsu (hoax) di media sosial. Jurnal Pemikiran Sosiologi, 4(2), 142. https://doi.org/10.22146/jps.v4i2.28586

Jusuf. (2020). Kominfo temukan 1.401 sebaran isu hoaks terkait Covid-19. Www. Aptika.Kominfo.Go.Id; Ditjen Aptika. https://aptika.kominfo. go.id/2020/05/kominfo-temukan-1-401-sebaran-isu-hoaks-terkaitcovid-19/

Leavy, P. (2017). Research design: Quantitative, qualitative, mixed methods, Arts-based, and community-based participatory research approaches. The Guilford Press.

Liliweri, A. (2009). Dasar-dasar komunikasi kesehatan. Pustaka Pelajar.

Mattola, A. G. (2020). Sektor pariwisata Sulsel sempat lumpuh di masa pandemi Covid-19. Www.Lintasterkini.Com; Lintas Terkini. https://lintasterkini. com/25/10/2020/sektor-pariwisata-sulsel-sempat-lumpuh-di-masapandemi-covid-19.html

Mawardi, D. (2020). Pariwisata di Bandung Barat lumpuh akibat Covid-19, PSBB Jakarta makin bikin runyam. Galamedianews.Com; Galamedia News. https://galamedia.pikiran-rakyat.com/humaniora/pr-35743060/ pariwisata-di-bandung-barat-lumpuh-akibat-covid-19-psbb-jakarta-makinbikin-runyam

Megasari, P. (2020). Kebijakan pemerintah Surabaya dalam menangani berita hoax (Studi kasus di Kota Surabaya). AL IMARAH: JURNAL PEMERINTAHAN DAN POLITIK ISLAM, 5(1), 67-83. http://dx.doi. org/10.29300/imr.v5i1.2918

MS, D. (2017). Media baru sebagai informasi budaya global. Jurnal Komunikator, 9(1), 38-47. Retrieved from https://journal.umy.ac.id/index.php/jkm/ article/view/2563

Mustofa, A. (2020). Dampak corona, kunjungan turis asing ke Nusa Penida kian menyusut. Radar Bali. https://radarbali.jawapos.com/ $\mathrm{read} / 2020 / 02 / 05 / 178027 /$ dampak-corona-kunjungan-turis-asing-kenusa-penida-kian-menyusut 
Prasanti, D. (2018). Health information of literation as prevention processes of hoax information in the use of traditional medicine in digital era (Literasi informasi kesehatan sebagai upaya pencegahan informasi hoax dalam penggunaan obat tradisional di era digital). Journal Pekommas, 3(1), 45. https://doi.org/10.30818/jpkm.2018.2030105

Putri, K. Y. S., Abdullah, Z. Bin, Safitri, D., Sugiyanta, L., \& Ramdan, A. K. (2020). Framing of health communication in Islamic Religious education in new media. Hayula: Indonesian Journal of Multidisciplinary Islamic Studies, 4(2), 189-202. https://doi.org/10.21009/004.2.03

Putri, K. Y. S., Adamu, A. A., Mukhtar, S., Safitri, D., Hafni, R. D., \& Nur, D. (2020). The impact of new media literacy and supply chain knowledge management on community economy in Indonesia. International Journal of Supply Hain Management, 9(3), 562-567. Retrieved from https://ojs. excelingtech.co.uk/index.php/IJSCM/article/view/4956

Rahmawati, O. P., Kharis, F. A., Rizayati, M. P., Oktariandari, S., \& Mukhtadi, M. (2019). Dampak penyebaran berita palsu (hoax) erupsi Gunung Agung. Jurnal Manajemen Bencana (JMB), 5(2). 13-20, https://doi. org/10.33172/jmb.v5i2.459

Rikumahu, P. (2020). Dampak pandemi covid-19 terhadap daya saing industri pariwisata. Gorontalo Development Review, 3(2), 126-139. https://doi. org/10.32662/golder.v3i2.1004

Santoso, D. H., \& Santosa, A. (2020). Covid-19 dalam ragam tinjauan perspektif (I. MBridge Press.

SATGAS COVID-19. (2020). Data kasus Covid-19 di Indonesia. Www.Covid19. Go.Id; Satuan Tugas Penanganan COVID-19. https://covid19.go.id/

Setyaningsih, R. (2017). Model literasi media berbasis kearifan lokal pada masyarakat kampung Dongkelan Kauman Daerah Istimewa Yogyakarta. Komuniti : Jurnal Komunikasi Dan Teknologi Informasi, 9(2), 118-125. https://doi.org/https://doi.org/10.23917/komuniti.v9i2.4520

Setyowati, L. (2021). Pemrosesan informasi pandemi covid-19 dari Facebook. Jurnal Komunikasi dan Media, 1(1), 45-54. https://doi. org $/ 10.24167 / \mathrm{jkm} . v 1 \mathrm{i} 1.2847$

Sugihamretha, I. D. G. (2020). Respon kebijakan: Mitigasi dampak wabah Covid-19 pada sektor pariwisata. Jurnal Perencanaan Pembangunan: The Indonesian Journal of Development Planning, 4(2), 191-206. https://doi. org/10.36574/jpp.v4i2.113 
Transformation of health communication literacy in the pandemic era (K. Y.S Putri, etc.)

Walakula, Y. B. (2020). Analisis eksistensi pariwisata Indonesia di tengah situasi pandemi corona virus disease ( Covid-19). NOUMENA: Jurnal Ilmu Sosial Keagamaan, I(1), 47-52. Retrieved from https://e-journal.iaknambon. ac.id/index.php/N/article/view/165 
Informasi, Vol. 51. No. 1. (2021), 93-110 